\title{
8. RESULTS OF BOREHOLE TELEVIEWER OBSERVATIONS IN THE CELEBES AND SULU SEAS ${ }^{1}$
}

\author{
Kimberly S. Kirchoff-Stein, ${ }^{2}$ Eli A. Silver, ${ }^{2}$ Daniel Moos, ${ }^{3}$ Colleen A. Barton, ${ }^{3}$ and Richard Jarrard ${ }^{4}$
}

\begin{abstract}
Borehole televiewer data were collected during Ocean Drilling Program Leg 124 to investigate stress orientations in the Sulu and Celebes sea basins. At Site 768C, in the Sulu Sea, televiewer logs were collected from 809-870 and 950-1250 meters below sea floor (mbsf). At Site 770C, in the Celebes Sea, televiewer logs were collected between 405-524 mbsf. No borehole breakouts were found during examination of these data. Calculation of the allowable stresses using a range of basaltic rock strengths shows that ambient stresses at the depths logged are lower than those necessary to cause breakouts in basalt.

Analysis of fractures visible in the borehole televiewer logs showed strong groupings of fracture orientations at both sites. At Site 768 , the main fracture trend is $\mathrm{N} 120^{\circ} \mathrm{E}$, dipping $60^{\circ} \mathrm{SW}$, with smaller groupings at $\mathrm{N} 117^{\circ} \mathrm{E}, 62^{\circ}$ $\mathrm{NE}$; $\mathrm{N} 64^{\circ} \mathrm{E}, 68^{\circ} \mathrm{SE}$; and N $35^{\circ} \mathrm{E}, 64^{\circ} \mathrm{E}$. At Site 770 , the main fracture orientations are $\mathrm{N} 119^{\circ} \mathrm{E}, 68^{\circ} \mathrm{NE}$ and $\mathrm{N}$ $143^{\circ} \mathrm{E}, 70^{\circ} \mathrm{SW}$. The preferred orientations of these high-angle fractures may represent a response to the present stress field, either by formation of new fractures or reactivation of older zones of weakness. The observed fracture pattern is compatible with extensional stresses related to subduction at the Cotabato and Negros trenches. Alternatively, the fractures may be relict features recording earlier stress conditions.
\end{abstract}

\section{INTRODUCTION}

The Sulu and Celebes sea basins are currently being overridden on their eastern margins by the Philippine Mobile Belt, which is colliding against the Palawan, Cagayan, and Sulu ridges (Fig. 1; Silver and Rangin, Chapter 3, this volume). This study was undertaken with the hope of determining the orientations of stresses in the Sulu and Celebes basins and, if possible, to relate these stresses to the present tectonic regime in these areas (Rangin, Silver, von Breymann, et al., 1990). We were also interested in comparing the stress orientations in the two basins to determine the degree of coupling between them.

The data used in this study were acquired with the borehole televiewer (BHTV), an ultrasonic device that provides highresolution images of the borehole wall. Two BHTV logs were acquired in Hole $768 \mathrm{C}$ in the Sulu Sea (Fig. 1), within the basaltic basement and lowest sediments (950-1250 mbsf) and in part of a tuff unit within the sediments (809-870 mbsf). In the Celebes Sea Basin, a BHTV log was collected in the basaltic basement and lower sediments (405-524 mbsf) of Hole 770C (Fig. 1). These logs were analyzed post-cruise for evidence of borehole breakouts and to determine any preferred fracture orientations at these sites.

\section{STRESS INFERENCES FROM BHTV DATA}

Borehole failure can occur as a result of compressive or tensile stress concentration around the borehole (Moos and Zoback, 1990). Under compressive stress, borehole breakouts occur at the azimuth of least principal stress, where the compressive stress concentration at the borehole wall are greatest (Bell and Gough, 1979; Zoback et al., 1985). When

\footnotetext{
${ }^{1}$ Silver, E. A., Rangin, C., von Breymann, M. T., et al., 1991. Proc. ODP, Sci. Results, 124: College Station, TX (Ocean Drilling Program).

2 Earth Sciences Board, University of California, Santa Cruz, CA 95064, U.S.A.

${ }^{3}$ Department of Geophysics, Stanford University, Stanford, CA 94305 , U.S.A.

${ }^{4}$ Lamont-Doherty Geological Observatory, Columbia University, Palisades, NY 10964, U.S.A.
}

present, breakouts have proven to be reliable indicators of stress orientation (e.g., Zoback and Zoback, 1980; Zoback et al., 1989). Tensile fractures form at the azimuth of greatest principal horizontal stress, where the borehole stress concentration is most tensile (Moos and Zoback, 1990). Tensile features may form due to localized stress concentrations during hydraulic fracturing experiments (Hubbert and Willis, 1957), but can also occur during drilling (Stock et al., 1985). Thermal stresses due to rapid cooling of the wellbore can also initiate or enhance tension cracks (Stephens and Voight, 1982). Thermally induced tension cracks have been noted in Hole 504B (Morin et al., 1990).

As pointed out by Moos and Zoback (1990), the presence of breakouts not only allows determination of the orientation of the principal horizontal stresses, but can also provide a lower bound on the horizontal stress difference if the rock strength is known. Similarly, the absence of breakouts provides an upper limit on the stress difference if the rock strength is known. If tension cracks are present, a further constraint can be placed on the ratio of effective horizontal stresses (Moos and Morin, in press).

\section{DATA ACQUISITION}

The BHTV is a wireline logging tool that produces a continuous, magnetically oriented picture of the borehole wall (Zemanek et al., 1970). It consists of a rotating acoustic transducer that emits a focused ultrasonic beam 600 times/ revolution, or 1800 times/s. The tool moves up the hole at 2.5 $\mathrm{cm} / \mathrm{s}$. The start of each scan is triggered at magnetic north by a fluxgate magnetometer in the tool. The BHTV can be operated at either high-frequency $(1.4 \mathrm{MHz})$ or low-frequency $(400 \mathrm{kHz})$ modes; both were used on Leg 124 . The reflected sonic signal and the magnetometer signal are continuously recorded on video tape for later processing. A real-time CRT display of the data is also photographed during acquisition to aid later processing efforts.

Two televiewer runs were obtained at Site 768 . With pipe set at 809 mbsf, the tool was run down to a firm bridge at 871 mbsf, which prevented logging of basaltic basement. Upcoming logs were obtained for the interval 870-809 mbsf, in a tuff unit within the sedimentary section. After moving drill pipe 


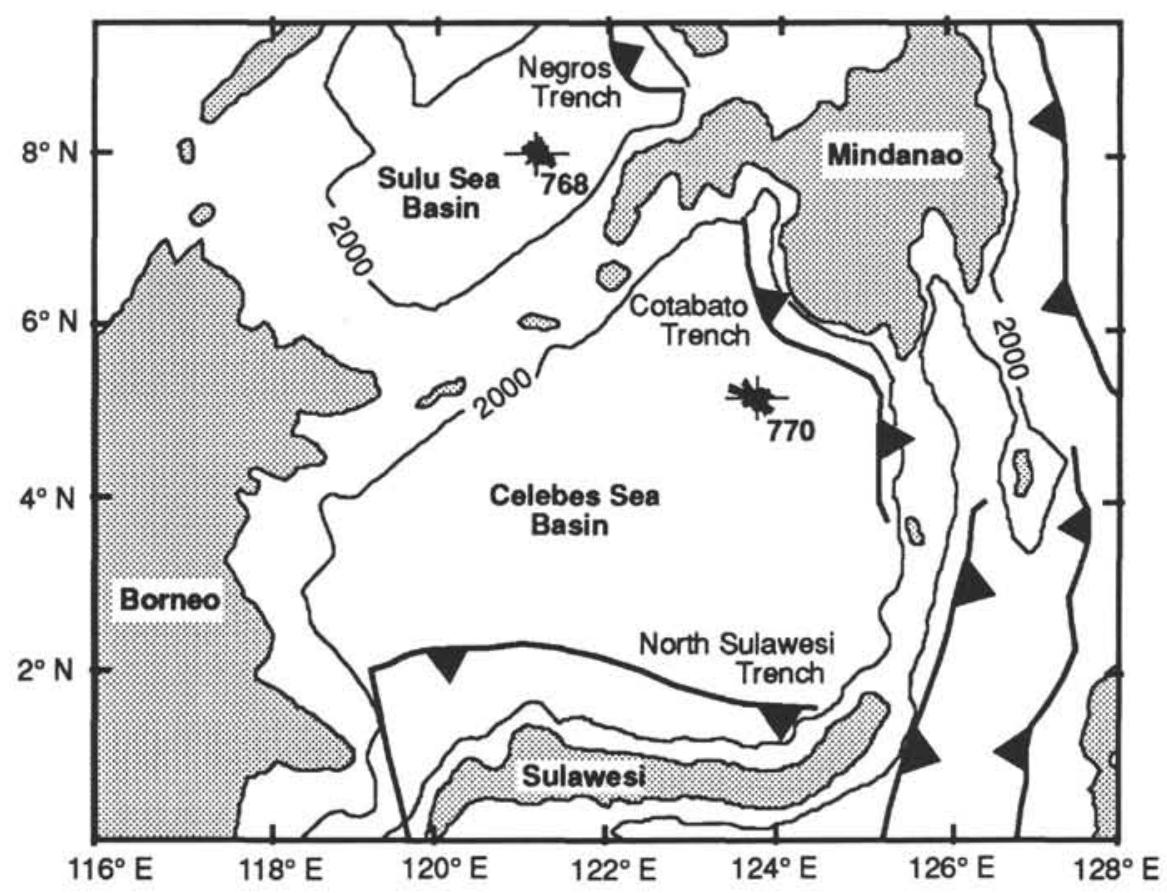

Figure 1. Map of the Sulu and Celebes seas. The location of Sites 768 and 770 are marked with a rose diagram illustrating the fracture orientations at each site. The location of the Negros and Cotabato trenches are also shown. The $2000-\mathrm{m}$ bathymetry contour is shown to better define the ridges.

and running one Schlumberger string, the second televiewer run logged the interval 1250-950 mbsf, corresponding to almost all of the basaltic basement and about $100 \mathrm{~m}$ of overlying sediment. Real-time data evaluation indicated that both runs were probably of marginal to poor quality.

At Site 770 the tool was run down into open hole but data acquisition was delayed for $2 \mathrm{hr}$ by slow and erratic rotation of the rotating mechanism, which we attributed to the very cold water. When the tool had warmed up sufficiently, the interval 524-405 mbsf was logged. One bowspring may have broken during tool entry into pipe; tool drag was higher than usual coming into the pipe, and a bowspring was missing when the tool was retrieved.

\section{DATA PROCESSING}

Post-cruise processing of the data was performed at Stanford University using techniques described in Barton (1988) and Barton et al. (in press). Digital amplitude and travel-time data from each reflected pulse were obtained from the analog field tapes using a MASSCOMP analog-to-digital processor. This processor uses programmable clocks triggered by the source pulse (Barton et al., 1988). While digitizing, the software adds a header to the data describing the BHTV tool specifications, fluid velocities, borehole deviation, and magnetic declination at the drill site. These values are used throughout the data processing and interpretation procedure to correctly orient and plot the data.

The shipboard photographs showed that the tool was off center in all three logs. Because of this asymmetry, the reflection from the exterior of the tool (the boot echo) and that of the borehole wall overlapped for about one-fourth of the circumference of the hole, masking the borehole image there. Also, we were unable to image the borehole wall farthest from the tool in some sections of both holes due to non-normal incidence of the signal from the uncentered tool. Figure 2 shows how non-normal incidence at the borehole wall, i.e., energy that intersects the wall at other than $90^{\circ}$, causes deflection of the return signal away from the tool. This results in paired blank bands centered around the point farthest from the tool (Fig. 2B). These bands become wider as the diameter of the hole increases. At these sites, this effect was pronounced in washed-out areas and became continuous in the sedimentary sections at the top of each hole. Georgi (1985) gives a more detailed discussion of this effect.

At Site 770 we imaged $90 \%-100 \%$ of the hole circumference from hole bottom to about 443 mbsf. Above this depth, only about $50 \%$ of the wellbore can be seen. At Site 768, about $60 \%-70 \%$ of the hole can be seen from $1110-1250$ mbsf. Above this depth the image quality degrades until less than one-fourth of the circumference of the hole is visible above 1050 mbsf. In the tuff section of this site (logged separately), less than $50 \%$ of the borehole wall can be seen. We restricted our analyses to those parts of the holes in which at least $60 \%$ of the hole was imaged.

In centered BHTV runs, the tool reflection or boot echo is removed from the data by simply delaying digitization until after its arrival, and multiple reflections are removed by stopping digitization before they arrive. We were unable to employ this technique, as the tool and borehole reflections overlapped for about one-fourth of the circumference of the wellbore in these uncentered logs. Instead, we used a low-cut amplitude filter to try to remove the lower amplitude tool reflection from that of the borehole. Caution was necessary when setting the digitization window length so as not to include multiple reflections from the near side of the hole while trying to encompass returns from the far side. We were generally able to filter out most of the tool reflection and all of the multiples with only minor degradation of the borehole reflection (Fig. 3).

Another problem was presented by stick-slip behavior of the tool during logging. This produces areas where the tool sticks slightly and then pulls up rapidly, causing several repeated scans followed by smeared reflections. Stick-slip is 


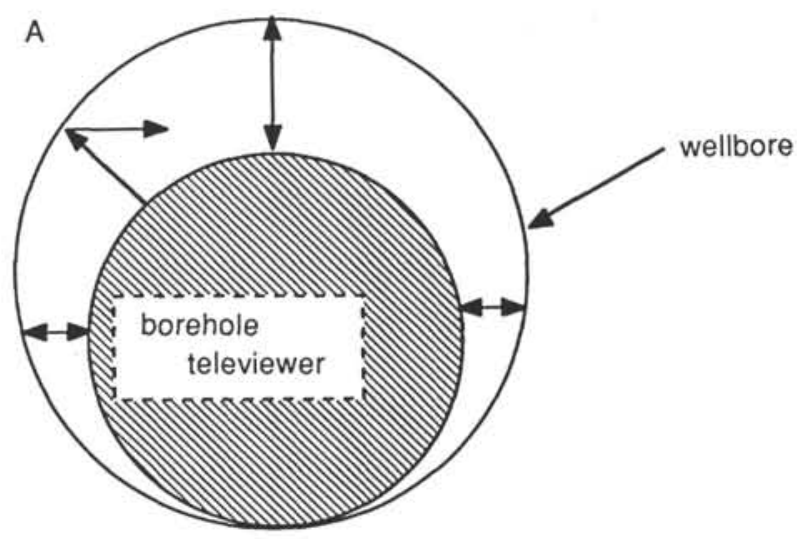

B

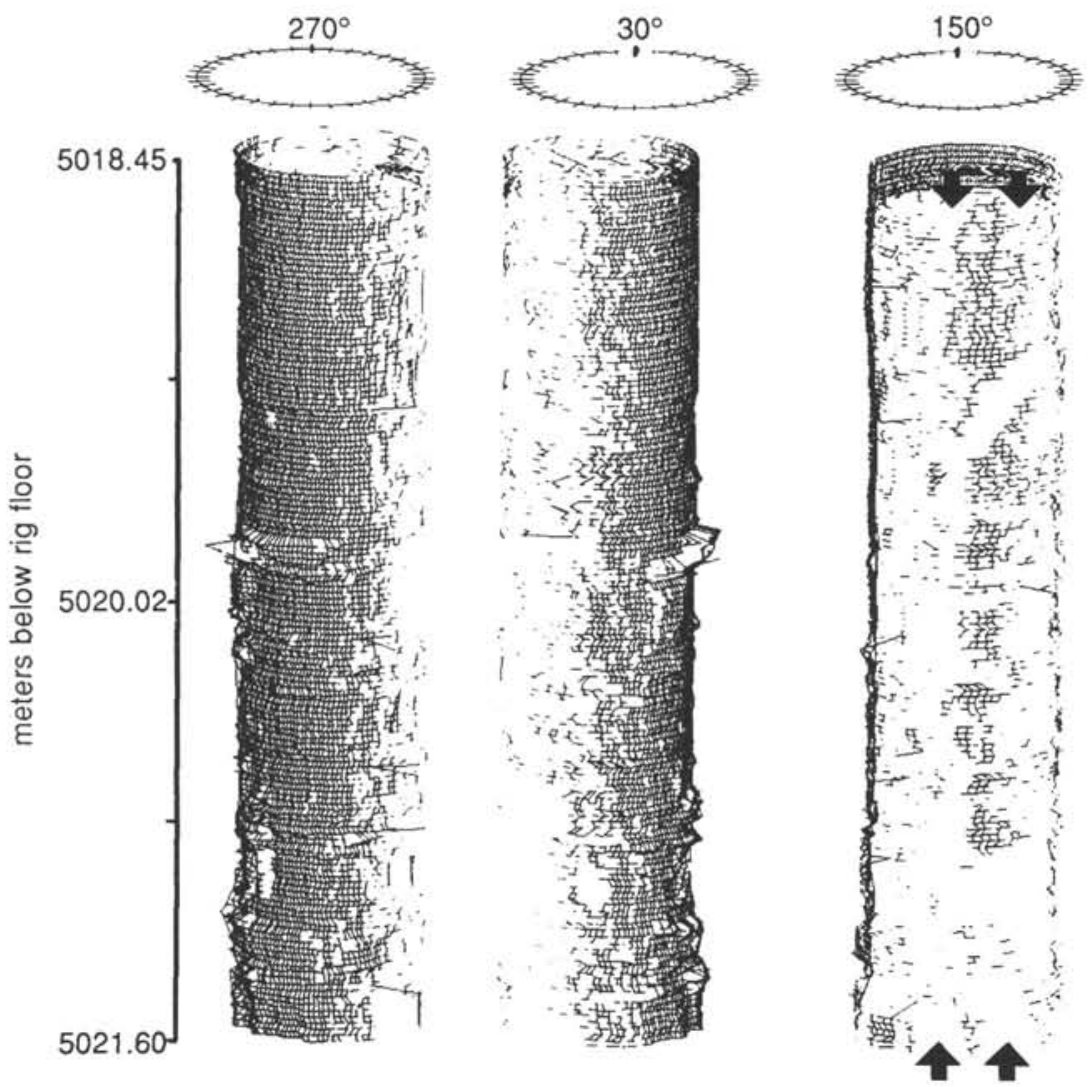

Figure 2. (A) Sketch of cross-section of a borehole showing off-centered borehole televiewer and several ray paths. Note how reflections from the far side of the hole may not return to the tool. (B) Off-centered, edited data from Site 770. The vertical white bands (arrows) are caused by deflection of the reflected energy away from the tool due to non-normal incidence.

very common in marine data and may be related to a combination of hole rugosity and wave-swell height during logging. The seas were so calm during logging of Site 770 that the heave compensator was turned off, which may have increased the stick-slip in this data set. However, having the tool dragging up one side of the hole was probably the main cause of the stick-slip. It is found pervasively throughout this data and needed to be removed prior to breakout analysis. This was done using an interactive borehole televiewer analysis package on the MASSCOMP computer.
The depth values of the data are somewhat altered during this process, as the software determines depth by dividing the thickness of a digitized section by the number of scans in this section. As stick-slip occurs randomly, the data depths will not be altered in a smooth, consistent manner. Prior to editing, the nontravel of the tool in the stuck sections and the too rapid travel in the slipped sections of the log roughly cancel out. Furthermore, the logging rate in the sections with no stick-slip is that reported for the logging run. While stick-slip removal is not a significant cause of error during breakout analysis, it 
alters fracture dips significantly. For this reason, we used unedited data for fracture analysis and fit curves only to those parts of the log without stick-slip. The fracture depths may be slightly in error, but the dips will be approximately correct.

Fracture strikes in the unprocessed data were also in error due to the tool being off-center (Barton et al., in press). The final processing steps were to median filter and center the data using the interactive analysis software discussed above (Barton et al., in press). It is important to smooth noise out of the data because noise degrades the accuracy of the centering algorithm. Because the data contained a lot of tool reflections, which the software sees as noise, we used a relatively large number of points (7-9) for our median filter and often had to filter more than once.

As discussed by Mastin (1988, Appendix B), the orientation of features in a borehole log may be erroneous due to deviation of the borehole. In a BHTV log, the orientation of features are determined relative to a trigger by a fluxgate magnetometer at magnetic north. In deviated boreholes the magnetometer triggers at the projection of magnetic north onto a plane perpendicular to the borehole axis. When this projected orientation is corrected for deviation by re-projecting onto the horizontal plane, it may differ from true magnetic north. This effect can be significant where the magnetic inclination is large (middle to high latitudes), especially when the hole trends at a large angle to north. Mastin (1988) provides tables of corrections for magnetic inclinations of $60^{\circ}$ and $70^{\circ}$. Deviation at Site 768 is $4-5^{\circ}$ at azimuth $55^{\circ}$, at Site 770 it is $3^{\circ}$ at azimuth $280^{\circ}$. Furthermore, as both sites are within $8^{\circ}$ of the Equator, magnetic inclination is nearly $0^{\circ}$ here. Because of the low deviation and magnetic inclination angles, the error in fracture orientations due to borehole deviation is negligible for this data, certainly much less than the $7^{\circ}-8^{\circ}$ predicted for these deviation angles at a magnetic inclination of $60^{\circ}$.

After data processing, we plotted three-dimensional cylindrical projections (Fig. 3a) and unwrapped (as if the cylinder is cut along one side and flattened) color amplitude and traveltime plots (not shown) of all the data to look for possible fractures and breakouts. We also examined the borehole shape in cross-section. Although we saw many faint fractures (Fig. 3B), no borehole breakouts were found at either site. We discuss the implications of this negative result below.

The unedited, median filtered, and centered data were transferred to a Macintosh II computer for preliminary fracture analysis using an interactive software package (Barton et al., in press). This package provides a flexible sine-wave that the user fits to a fracture. The program then calculates and records the fracture depth, strike, and dip. Fracture orientations were picked for the depth range 445-522 mbsf at Site 770 and 1175-1246 mbsf at Site 768 .

The pervasive stick-slip made fracture location difficult. To guard against fitting different curves to separate sections of a single fracture that were divided by a stick-slip section, we examined an edited (stick-slip removed) plot of the same data. We also used the edited data to help locate shallow-dipping features, which were hard to see in the unedited data. After all fractures were recorded, we plotted contours of poles to the fracture planes and rose diagrams of fracture orientations on equal-area stereonets for each site, to look for consistent trends. We then plotted the number of fractures per depth interval. These results are discussed below.

\section{DATA ANALYSIS}

\section{Implications of the Absence of Borehole Breakouts}

Borehole breakouts were not imaged by the BHTV at either Site 768 or 770 . Using the method of Moos and Zoback (1990), we have determined the allowable stress conditions at the bottom of each hole, where stresses are likely to be greatest, and the type of breakouts possible under these conditions (Figs. 4 and 5). In preparing these graphs, we assumed that the ratio of maximum to minimum effective stress can not exceed that necessary to cause motion on pre-existing faults situated at an optimum orientation to the stress field (Sibson, 1974; Brace and Kohlstedt, 1980). We also assumed that the stress due to the overburden $\left(S_{\mathrm{v}}\right)$ is one of the principal stresses; the other two principal stresses $\left(S_{\mathrm{H} \max }\right.$ and $S_{\text {hmin }}$ ) must then act in orthogonal horizontal directions. This assumption is compatible with earthquake focal mechanism studies (Zoback et al., 1989) which show that almost all $P$ or $T$ axes for shallow intraplate earthquakes are within $10^{\circ}-15^{\circ}$ of vertical. The limiting stress ratio is then (Jaeger and Cook, 1979):

$$
\left(S_{1}-P_{0}\right) /\left(S_{3}-P_{0}\right)=\left[\left(1+\mu^{2}\right)^{1 / 2}+\mu\right]^{2},
$$

where S1 and S3 are the maximum and minimum principal stresses and $\mathrm{P} 0$ is the ambient pore pressure.

The graphs in Figures 4 and 5 were constructed using equation (1) and Anderson's (1951) theory of faulting (Moos and Zoback, 1990). These figures show the range of acceptable values of horizontal principal stresses for normal (NF), reverse (RF), and strike-slip (SS) faulting environments for the conditions at Site 768 (Fig. 4) and at Site 770 (Fig. 5). In Anderson's theory, the failure bounds for normal faulting are $S_{1}=S_{\mathrm{v}}$ and $S_{3}=S_{\text {hmin }}$; for reverse faulting the bounds are $S_{1}$ $S_{1}=S_{\mathrm{Hmax}}$ and $S_{3}=S_{\mathrm{v}}$, and for strike-slip faulting the bounds are $S_{1}=S_{\mathrm{H} \max }$ and $S_{3}=S_{\mathrm{hmin}}$. The reverse and strike-slip fields are separated by the vertical line $S_{\mathrm{hmin}}=S_{\mathrm{v}}$, and the strike-slip and normal fields by the horizontal line $S_{\mathrm{H} \max }=S_{\mathrm{v}}$. The outer boundaries of the allowable stress states are the frictional limits for the different faulting environments as defined by equation (1). Because $S_{\mathrm{H} \max }>S_{\mathrm{hmin}}$ by definition, the stress state must lie above the $45^{\circ}$ sloping line.

Following Brace and Kohlstedt (1980), we used a coefficient of friction, $\mu$, of 0.85 . Byerlee $(1968,1978)$ showed that the coefficient of friction is 0.85 for almost all geologic materials over a range of normal stresses from $3 \mathrm{MPa}$ to 1.7 $\mathrm{GPa}$. Both Sites 768 and 770 are well within this range. Varying $\mu$ by $5 \%-10 \%$ will shift the faulting limits slightly but will not vary the results shown on these figures. Pore pressure, $P_{0}$, is taken to be hydrostatic, based on measurements in holes 504B (Anderson and Zoback, 1982), 395A (Hickman et al., 1984), and 597C (Shipboard Scientific Party, 1986), which showed pore pressures within $2.5 \%$ of hydrostatic. Using a higher pore pressure, as might be found in over-pressured areas, will result is a smaller range of acceptable stress levels, with a lower maximum $S_{\mathrm{Hmax}}$ and a higher minimum $S_{\mathrm{hmin}}$ :

By simple elastic Mohr-Coulomb analysis, compressive failure (breakouts) occurs at the borehole wall due to differences between circumferential and radial stress when the circumferential stress concentration exceeds the rock strength, $C$ (Zoback et al., 1985, Moos and Zoback, 1990). The breakout fields can then be defined by $S_{\mathrm{H} \max } \geq 1 / 3\left(C+S_{\mathrm{hmin}}+\right.$ $\left.2 P_{0}\right)$ for failure only at the azimuth of $S_{\mathrm{hmin}}$, and $S_{\mathrm{hmin}} \geq 1 / 3(C$ $\left.+S_{\mathrm{Hmax}}+2 P_{0}\right)$ for failure everywhere around the hole (Moos and Zoback, 1990). These limits can be compared with the allowable stress states described above to determine the likelihood of breakout formation.

Basalt rock strength, $C$, ranges between 170-224 MPa (Clark, 1966; Carmichael, 1982; Bauer and Handin, 1985). As the actual rock strength has not been measured at either site 768 or 770 , we calculated breakout limits for minimum $(C=$ $170 \mathrm{MPa})$, maximum $(C=224 \mathrm{MPa})$ and average $(C=200$ $\mathrm{MPa}$ ) rock strengths (Figs. 4 and 5). 
A
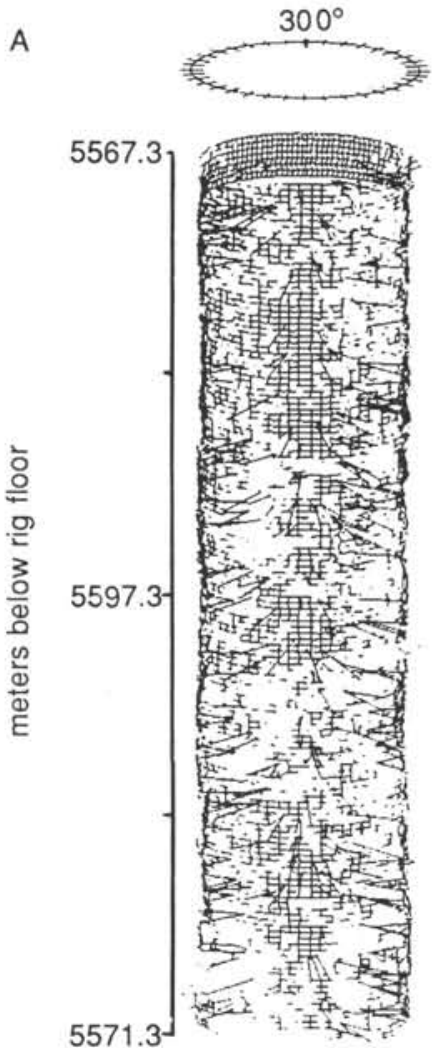
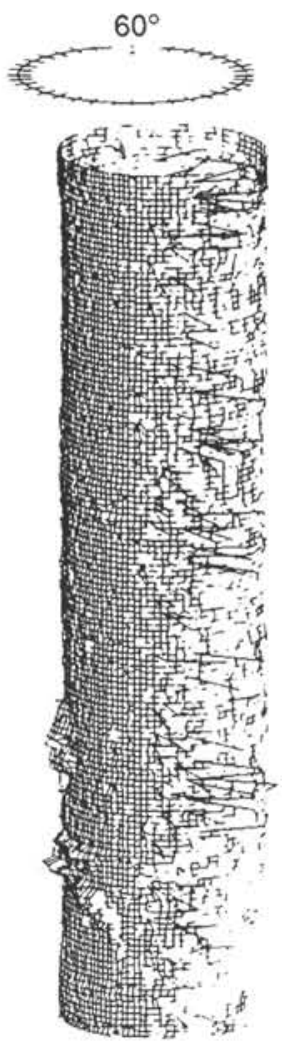

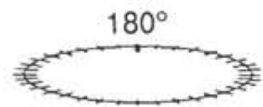

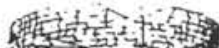

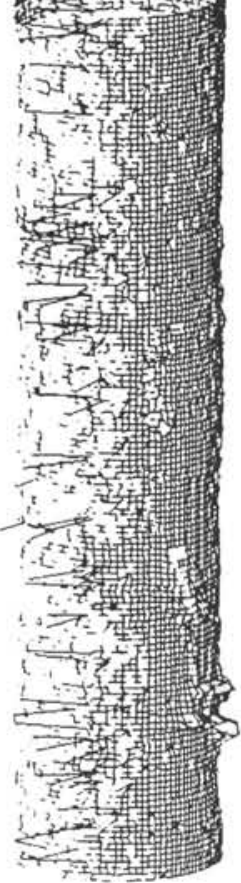

Figure 3. (A) Three-dimensional cylindrical projections of edited, uncentered borehole televiewer data from Site 768. Note white bands due to non-normal incidence as shown in Figure 2. Spikes at azimuths $60^{\circ}$ and $180^{\circ}$ are due to reflections from the tool. (B) Same section as (A) with fracture orientations marked.

B
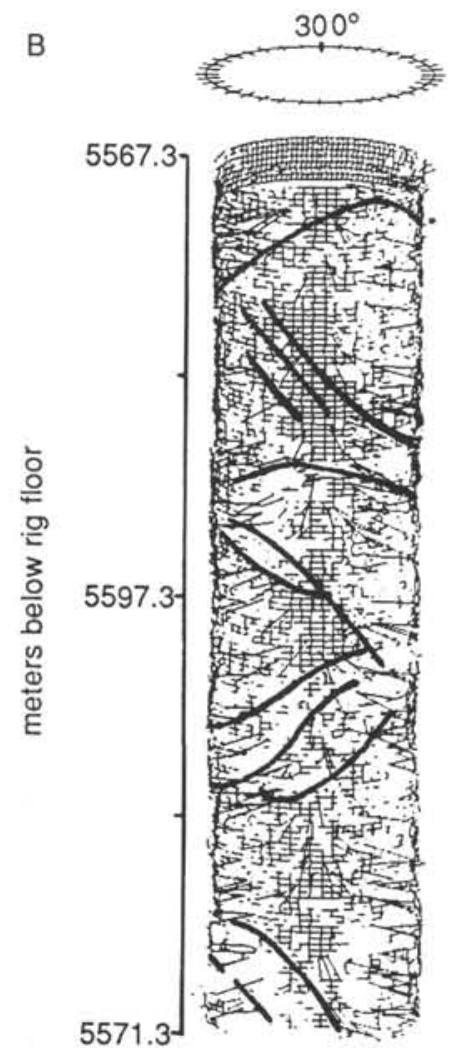
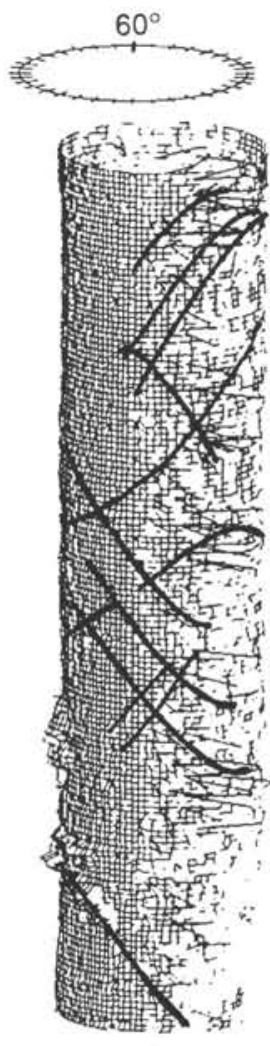
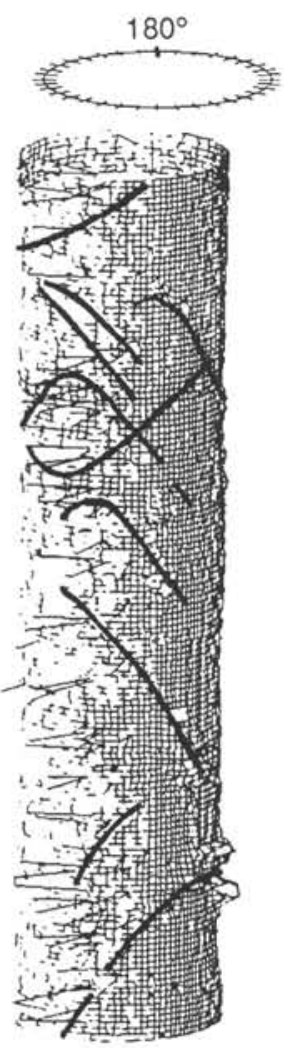

Figure 3 (continued). 


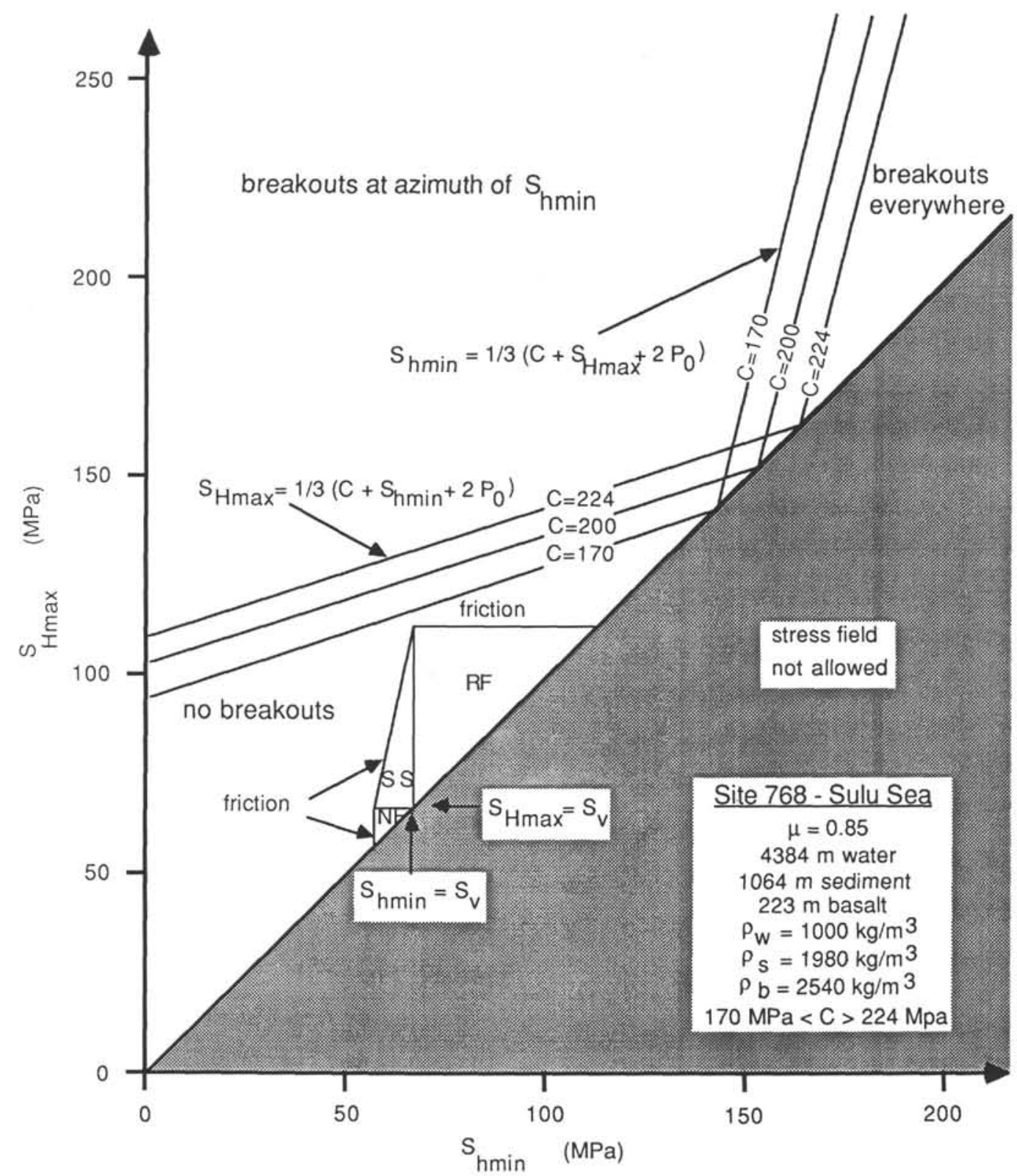

Figure 4. Graph showing permissible stress fields and stresses necessary to cause borehole breakouts at the lowest depth logged at Site 768. Limits of breakout fields have been calculated for minimum $(\mathrm{C}=170 \mathrm{MPa})$, maximum $(C=224 \mathrm{MPa})$, and average $(C=200 \mathrm{MPa})$ basaltic rock strengths. $\mu=$ friction, $\rho \mathrm{w}=$ density of water, $\rho \mathrm{s}=$ density of sediment, $\rho \mathrm{b}=$ density of basalt. See text for discussion of methods used to construct this graph.

Figures 4 and 5 were prepared using the depths and average densities measured during drilling at Sites 768 and 770 (Rangin, Silver, von Breymann et al., 1990). Site 768 (Fig. 4) has $4384 \mathrm{~m}$ of water at $1000 \mathrm{~kg} / \mathrm{m}^{3}, 1046 \mathrm{~m}$ of sediments at 1950 $\mathrm{kg} / \mathrm{m}^{3}$, and $222.5 \mathrm{~m}$ of basement at $2550 \mathrm{~kg} / \mathrm{m}^{3}$. Site 770 (Fig. 5) has $4505 \mathrm{~m}$ of water at $1000 \mathrm{~kg} / \mathrm{m}^{3}, 424 \mathrm{~m}$ of sediments at $1675 \mathrm{~kg} / \mathrm{m}^{3}$, and $108 \mathrm{~m}$ of basalt at $2700 \mathrm{~kg} / \mathrm{m}^{3}$. In both Sites 768 and 770 the allowable state of stress is far lower than that required for the formation of breakouts. Planned measurements of rock strengths using samples taken from recovered cores may help define the stress regime if the rock proves to be substantially weaker than the $200 \mathrm{MPa}$ value used here.
This is particularly true for the deeper of the two sites, 768 (Fig. 4).

Interestingly, breakouts were observed in Hole 504B beginning at the relatively shallow depth of $700 \mathrm{mbsf}$ (including 274-m sediments). From this, Moos and Zoback (1990) determined that the stress state at that site must be a highly compressive, transitional strike-slip/reverse one. Site 768 penetrated to a total depth of almost 1270 mbsf; however, more than $1 \mathrm{~km}$ of that was sediments. Even so, the absence of breakouts at Site 768 indicates that horizontal stresses here are either lower, or less deviatoric, than those at equivalent depth in Hole 504B. 


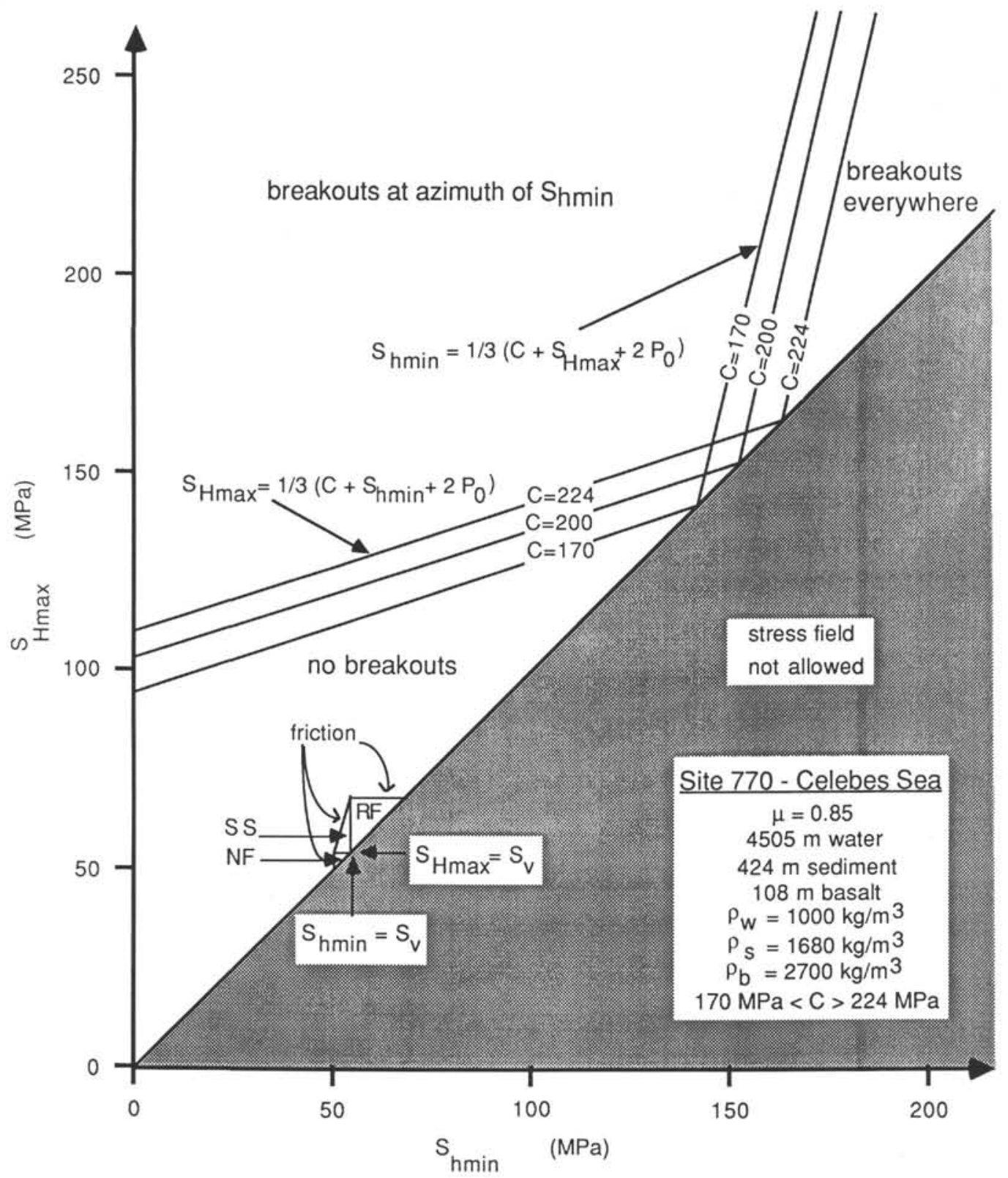

Figure 5. Graph showing permissible stress fields and stresses necessary to cause borehole breakouts at the lowest depth logged at Site 770. See text for discussion of methods used to construct this graph, and Figure 4 for definition of symbols used.

\section{Fracture Analysis}

As described earlier, a preliminary analysis was performed on the lower sections of the BHTV log in Sites 768 and 770 to determine fracture orientations. A lower hemisphere equalarea contour plot of poles to planes (Figs. 6A, 7A, 8A, C), a rose diagram of fracture orientations (Figs. $6 \mathrm{~B}, 7 \mathrm{~B}, 8 \mathrm{~B}, 8 \mathrm{D}$ ), and a fracture frequency vs. depth plot (Figs. 9A, 9B) were prepared for each location. The contour plots were prepared using the method of Kamb (1959), which yields contours of standard deviation (sigma) instead of numbers of poles. Sigma is the standard deviation of the total number of poles in a given sampling area under random sampling. Sigma and counting area are determined using a statistical relation and depend on the number of poles plotted (Seeburger and Zoback, 1982).
The density expected with random orientations is 3 sigma; densities $\geq 6$ sigma are statistically significant.

In the Sulu Sea we recorded 570 fracture orientations for the interval from 1166 to 1247 mbsf. The contour plot of poles to the fracture planes (Fig. 6A) shows a concentration of planes striking around $\mathrm{N} 120^{\circ} \mathrm{E}$ and dipping $60^{\circ} \mathrm{SW}$; with secondary clusters at $\mathrm{N} 117^{\circ} \mathrm{E}, 62^{\circ} \mathrm{NE}$; $\mathrm{N} 64^{\circ} \mathrm{E}, 68^{\circ} \mathrm{SE}$; and $\mathrm{N} 35^{\circ} \mathrm{E}, 64^{\circ} \mathrm{E}$. Plots for each $15-\mathrm{m}$ section (not shown) were also prepared. Although there was some variability in fracture orientation with depth, the general trend is similar to that for the entire Site.

The apparent lack of shallow-dipping features at Site 768 (Fig. 6) may be due to the pervasive stick-slip during televiewer logging of this site, which made location of these features difficult. However, detailed study of cores and BHTV 
A

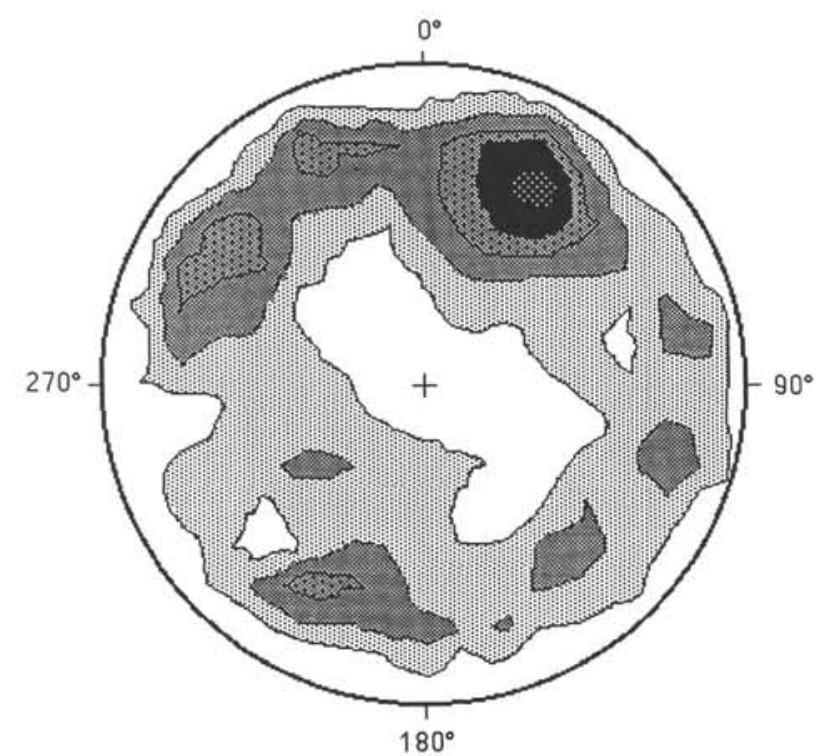

Site 768 - Sulu Sea

equatarea projection

number of data points $=570$

contour interval $=2$ sigma

expected number $=8.86$

counting circle area $=.016$

significance level $=3$ sigma
B

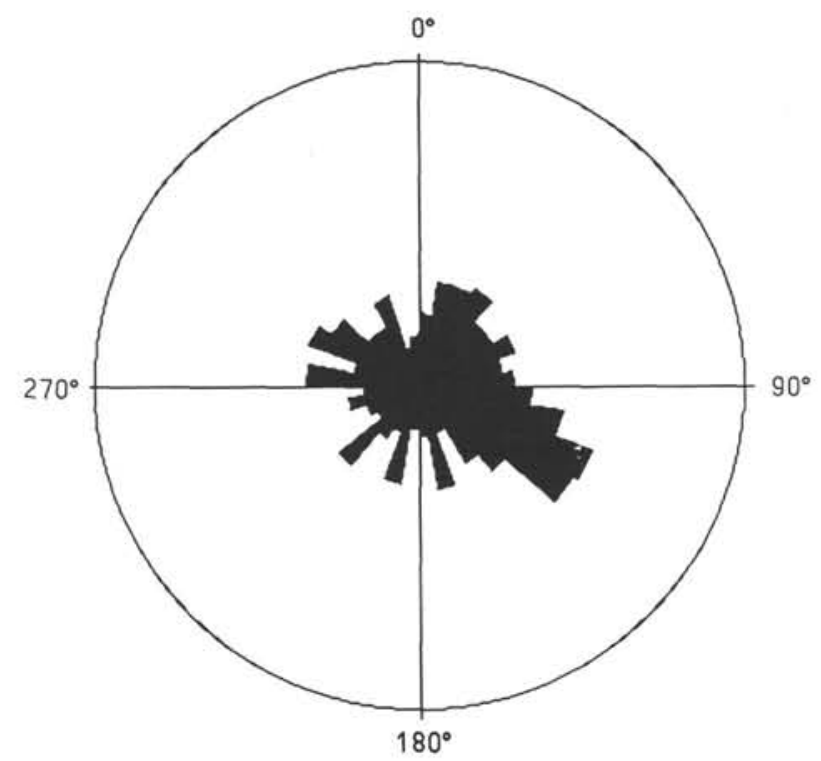

Site 768 - Sulu Sea

number of data points $=570$

circle radius $=10 \%$

size of largest petal $=6 \%$

between $110^{\circ}$ and $120^{\circ}$

Figure 6. Site 768: (A) Lower hemisphere Kamb equal-area contour plot of poles to fracture planes, see Table 1 for strikes and dips. Sigma $=$ standard deviation of the total number of points in a given area under random sampling. Sigma and counting circle area are determined by a statistical relationship from the number of data points (Kamb, 1959). The expected density for no preferred orientations is 3 sigma; densities greater than 6 sigma represent significant preferred fracture orientations. First contour interval is 2 sigma. (B) Equal-area rose diagram of fracture orientations for (A).

logs from ODP Leg 123 has shown a similar dearth of low-angle fractures (Gradstein, Ludden, et al., 1990), suggesting that low-angle fractures may be uncommon in much of the oceanic crust. Also, preliminary descriptions of the core from Hole 768C (Rangin, Silver, von Breymann et al., 1990) noted mainly steeply dipping features in the basement here. Finally, a vertical borehole will preferably encounter more shallowdipping than steeply-dipping fractures (Newmark et al., 1985). Given this, the fact that a very large percentage of the fractures imaged in this hole are high-angle probably reflects a preponderance of high-angle fractures in crust at this site.

In the Celebes Sea, 308 fractures were recorded for the depths 445-524 mbsf. A lower hemisphere equal-area contour plot of the poles to the fracture planes is shown in Figure 7A and a rose diagram of fracture orientations in Figure $7 \mathrm{~B}$. Fracture orientations cluster mainly around $\mathrm{N} 119^{\circ} \mathrm{E}, 68^{\circ} \mathrm{NE}$, and $\mathrm{N} 143^{\circ} \mathrm{E}, 70^{\circ} \mathrm{W}$. Secondary clusters are found at $\mathrm{N} 76^{\circ} \mathrm{E}$, $66^{\circ} \mathrm{SE}$, and $\mathrm{N} 73^{\circ} \mathrm{E}, 60^{\circ} \mathrm{NW}$. Although there is again a strong preference toward dips of $60^{\circ}-70^{\circ}$, the pattern shows a higher percentage of steeply dipping fractures than those in Site 768. The sills and flows of the lower part of the basement (Figs. 8A, $8 \mathrm{~B})$ show a much stronger clustering around $\mathrm{N} 119^{\circ} \mathrm{E}, 68^{\circ} \mathrm{NE}$ and $\mathrm{N} 143^{\circ} \mathrm{E}, 70^{\circ} \mathrm{W}$ than the pillow basalts (Figs. 8C, 8D) above them. The core shows that these pillows are strongly brecciated (Rangin, Silver, von Breymann, et al., 1990), presumably during emplacement. The more random orientations of the fractures in the pillows is more likely due to this brecciation than to any past or present stress orientation. As with Site 768 , there is an obvious lack of shallow-dipping features. This absence may be due to difficulties identifying these features with the pervasive stick-slip in this hole, but it could reflect a characteristic of much of the oceanic crust (see above).

The plots of fracture occurrence with depth for both sites (Figs. 9A, 9B) show considerable variability with depth. Some of the isolated spikes, such as that between 1220 and 1225 mbsf in Site 768 are either random fluctuations or the result of variations in the quality of the borehole image. The trends observed in these figures appear to match, in a general way, the fracture frequency in the cores (Rangin, Silver, von Breymann, et al., 1990), and may depend on the lithologies involved.

\section{DISCUSSION}

\section{Possibility of Thermal Fracturing}

Morin et al. (1990) report the presence of drilling-induced thermal fractures at Hole 504B. These fractures form as the result of thermal stresses caused by large differences in drilling fluid and rock temperature. When the drilling fluid is colder than the rock, as occurs in subsea drill holes, the induced stresses will be extensional (Moos and Zoback, 1990). However, very large temperatures are generally required to create thermal fractures. For example, in Hole 504B the 
A

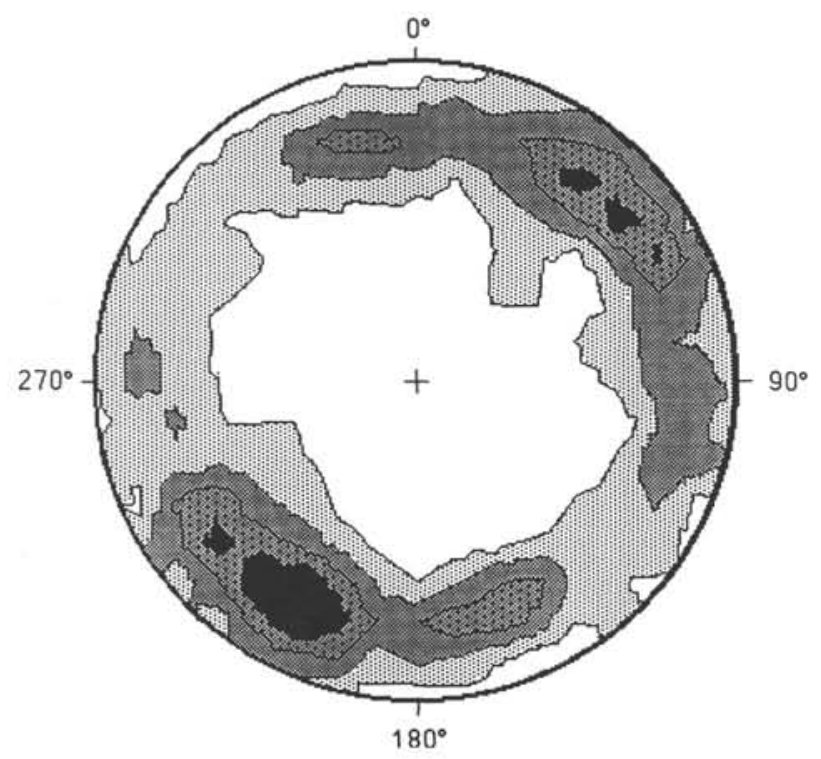

Site 770 - Celebes Sea Sills, Flows, and Pillow Basalts equakarea projection

number of data points $=308$

contour interval $=2$ sigma

expected number $=8.74$

counting circle area $=.028$

significance level $=3$ sigma
B

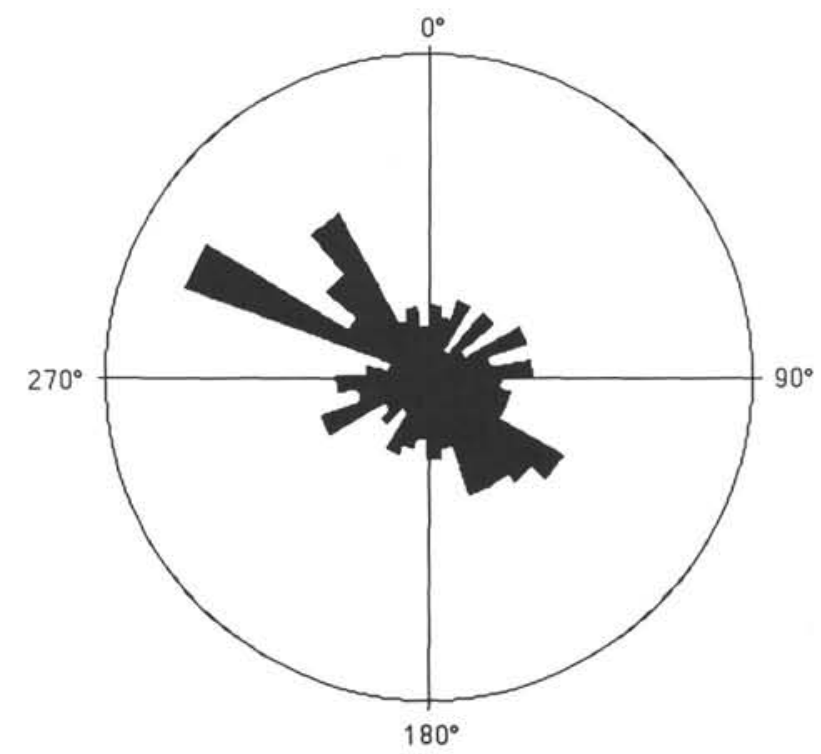

Site 770 - Celebes Sea Sills, Flows, and Pillows

number of data points $=308$

radius of circle $=10 \%$

size of largest petal $=8 \%$

between $290^{\circ}$ and $300^{\circ}$

Figure 7. Site 770: (A) Lower hemisphere Kamb equal-area contour plot of poles to fracture planes for basement section, see Table 1 for strikes and dips, Figure 6 for explanation of Kamb (1959) method. (B) Equal-area rose diagram of fracture orientations for (A).

temperature difference between the surface seawater used as drilling fluid and the in situ rock is estimated at $120^{\circ} \mathrm{C}$ by Morin et al. (1990). This requires no heating or cooling of the seawater as it travels through the drill pipe and is certainly an upper limit on the wellbore cooling at this site. The thermal stresses generated by wellbore cooling will effectively reduce the tensile strength $(T)$ by the magnitude of the tensile thermal stress, yielding an effective tensile strength $\left(T^{*}\right)$. Fracturing will occur when $S_{\mathrm{H} \max }=3 S_{\mathrm{hmin}}-2 P_{0}+T^{*}$. Thermally induced tension cracks will form at the azimuth of $\mathrm{S}_{\mathrm{Hmax}}$. Could thermal fracturing be responsible for the clustering of fracture orientations seen at Sites 768 and 770 (Table 1)?

As discussed by Moos and Zoback (1990), calculating the thermal effect of circulation requires accurate knowledge of such drilling parameters as pumping rate, rotation rate, fluid viscosity, and temperature profile outside the pipe. They give equations for accurate calculation of the thermal stresses.

Unfortunately, we do not have sufficient information at either Site 768 or 770 to make accurate calculations. Following Morin et al. (1990) and Moos and Zoback (1990), we can estimate the thermal stress at each site (Stephens and Voight, 1982) using:

$$
\sigma \theta=\alpha E \Delta T /(1-v),
$$

Where $\sigma \theta$ is the (tensile) circumferential stress, $\alpha$ is the coefficient of thermal expansion, $E$ is Young's modulus, $\Delta \mathrm{T}$ is the temperature difference between the adjacent rock and borehole fluid, and $v$ is Poisson's ratio. For basalts, $4.4 \times 10^{-6}$ ${ }^{\circ} \mathrm{C}^{-1} \leq \alpha \leq 6.4 \times 10^{-6}{ }^{\circ} \mathrm{C}^{-1}, 50 \mathrm{GPa} \leq E \leq 70 \mathrm{GPa}, 0.17 \leq v$ $\leq 0.25$, and $23 \mathrm{MPa} \leq T \leq 43 \mathrm{MPa}$ (Clark, 1966; Carmichael, 1982). Following Moos and Zoback (1990), we will use average basalt values of $\alpha=5.4 \times 10^{-6}{ }^{\circ} \mathrm{C}^{-1}, E=60 \mathrm{GPa}, v=0.2$, and $T=28.5 \mathrm{MPa}$. Substituting these values into equation (2) gives

$$
\sigma \theta=40.5 \mathrm{MPa} / 100^{\circ} \mathrm{C} \text {. }
$$

The number of temperature readings collected at Sites 768 and 770 was insufficient to allow calculation of equilibrium temperatures. The bottom hole temperature $87.8^{\circ} \mathrm{C}$ recorded on a maximum-recording thermometer at the bottom of Site 768 was considered to be closest to equilibrium (Rangin, Silver, von Breymann et al., 1990). No bottom hole temperature was reported for Site 770 , but the thermal gradient indicates a non-equilibrium temperature of $68.4^{\circ} \mathrm{C}$ at the bottom of the hole. Surface seawater is used as a drilling fluid in ODP holes. Although this enters the drill pipe at an average temperature of $28^{\circ} \mathrm{C}$, it is cooled as it travels down pipe through seawater and warmed as it passes through warmer rock. The amount of warming at Sites 768 and 770 is unknown. We used the difference between unwarmed surface water and the non-equilibrium bottom hole temperature to estimate the maximum thermal stress possible at the bottom of the hole. At Site 768 the temperature difference is $60^{\circ} \mathrm{C}$; this yields a thermal stress of $24.3 \mathrm{MPa}$ and an effective tensile strength of 4.2 $\mathrm{MPa}$. At Site 770 the temperature difference is $40^{\circ} \mathrm{C}$, indicating a maximum thermal stress of $16.4 \mathrm{MPa}$ and an effective tensile strength of $12.1 \mathrm{MPa}$. The temperatures used here are probably lower than the equilibrium temperatures at 


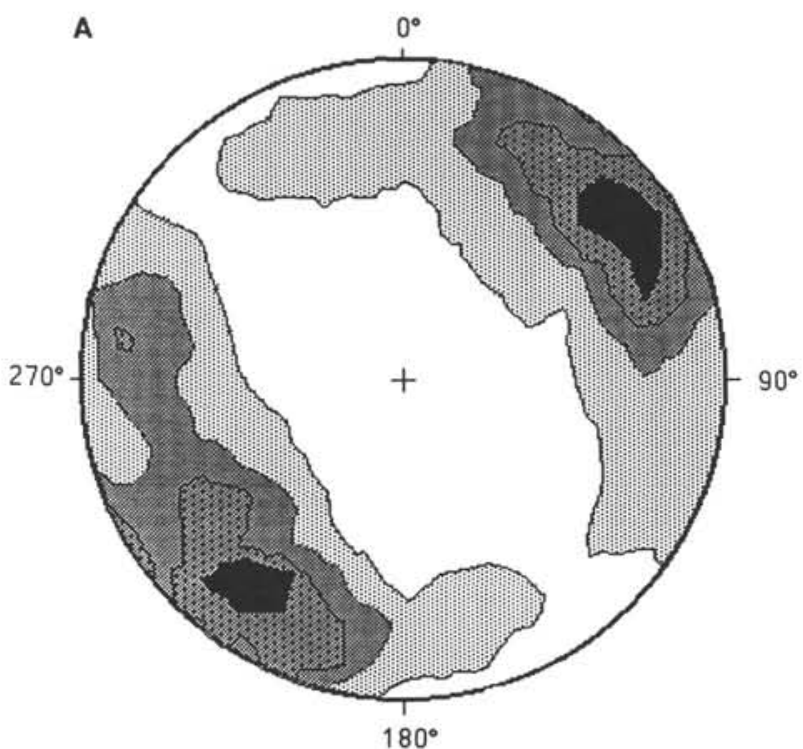

Site 770 - Celebes Sea Sills and Flows

equal area projection

number of data points $=185$

contour interval $=2$ sigma

expected number $=8.58$

counting circle area $=.046$

significance level $=3$ sigma

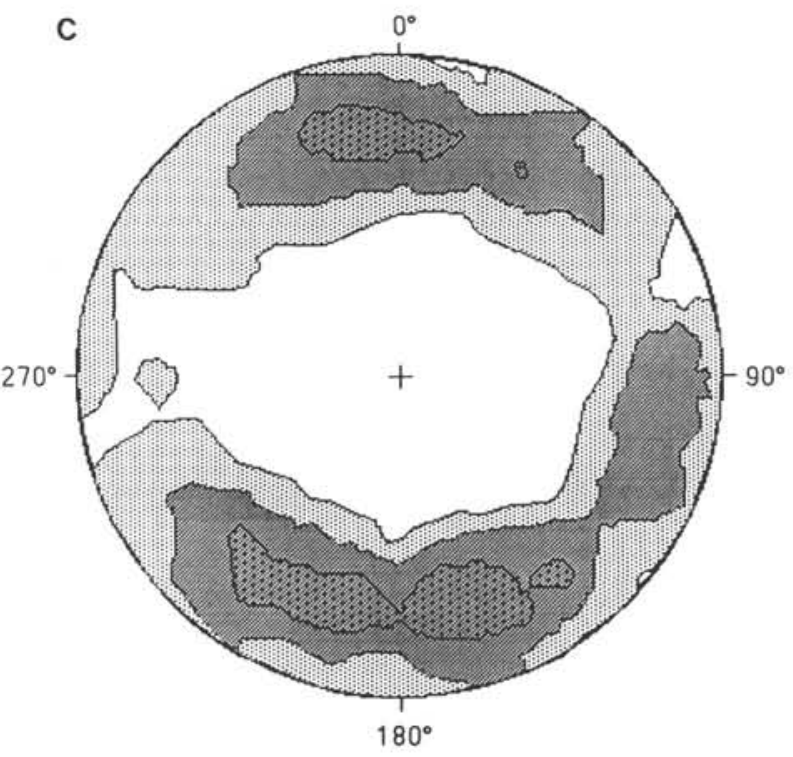

Site 770 - Celebes Sea Pillow Basalts

equalarea projection

number of data points $=123$

contour interval $=2$ sigma

expected number $=8.39$

counting circle area $=.068$

significance leve $\mathrm{l}=3$ sigma

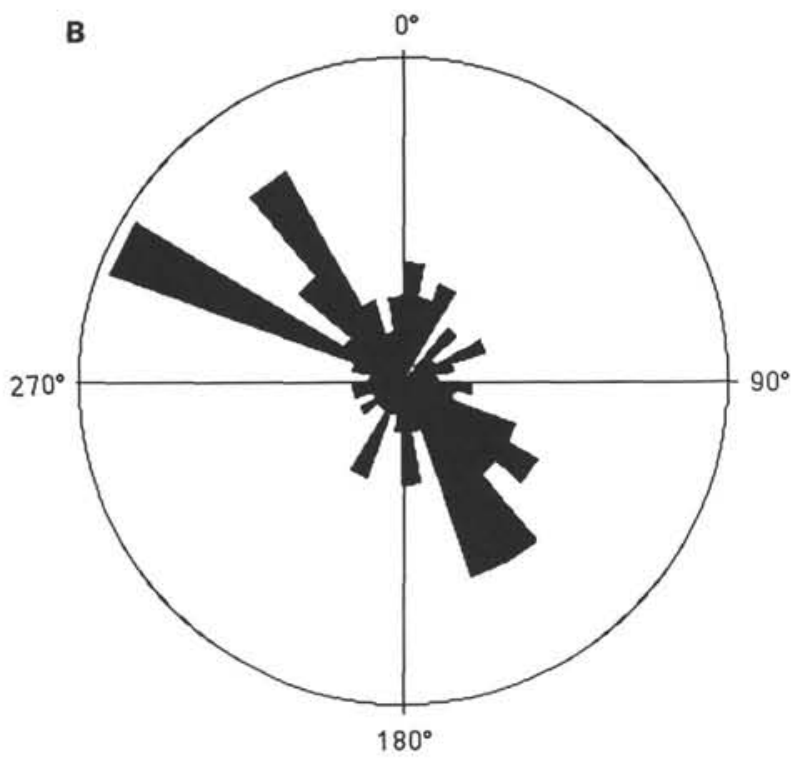

Site 770 -Celebes Sea Sills and Flows

number of data points $=185$

circle radius $=10 \%$

size of largest petal $=10 \%$

between $290^{\circ}$ and $300^{\circ}$

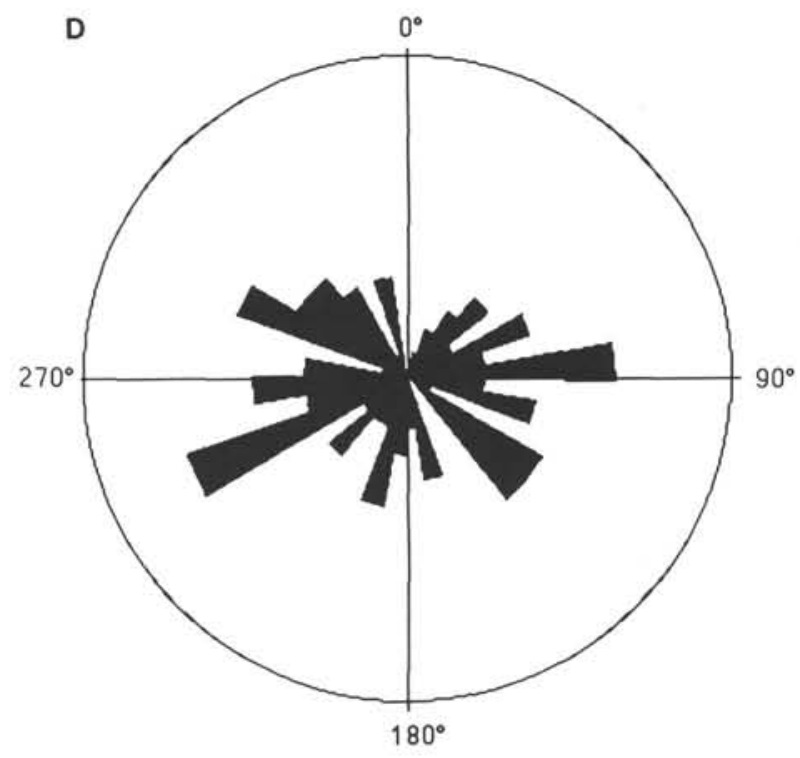

Site 770 -Celebes Sea Pillow Basalts

number of data points $=123$

radius of circle $=10 \%$

size of largest petal $=7 \%$

between $240^{\circ}$ and $250^{\circ}$

Figure 8. Site 770: (A) Lower hemisphere Kamb equal-area contour plot of poles to fracture planes for sills and flows of lower basement section. (B) Equal-area rose diagram for (A). (C) Lower hemisphere Kamb equal-area contour plot of poles to fracture planes for pillow basalt units at the top of the basement. (D) equal-area rose diagram for (C). See Figure 6 for explanation of Kamb (1959) diagram. 
A

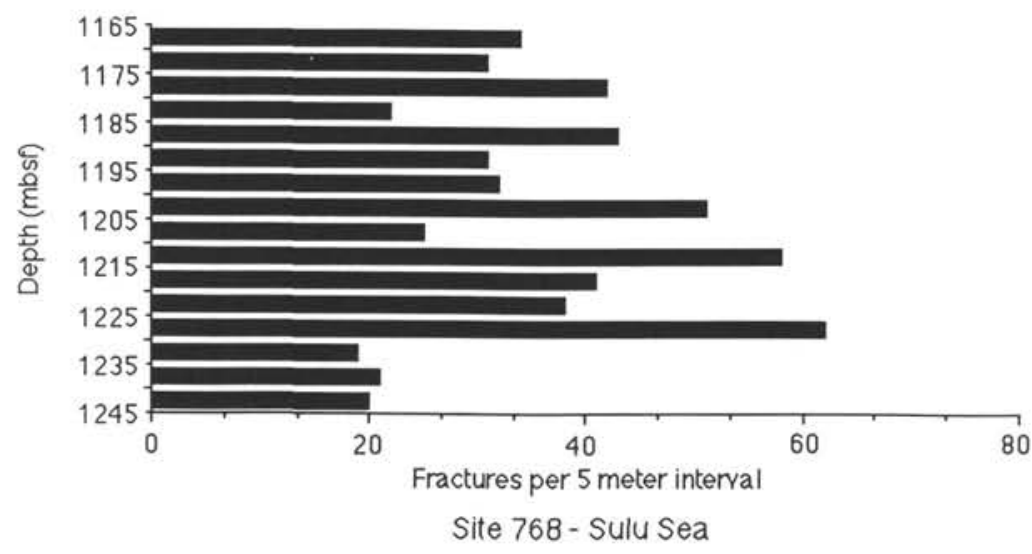

B

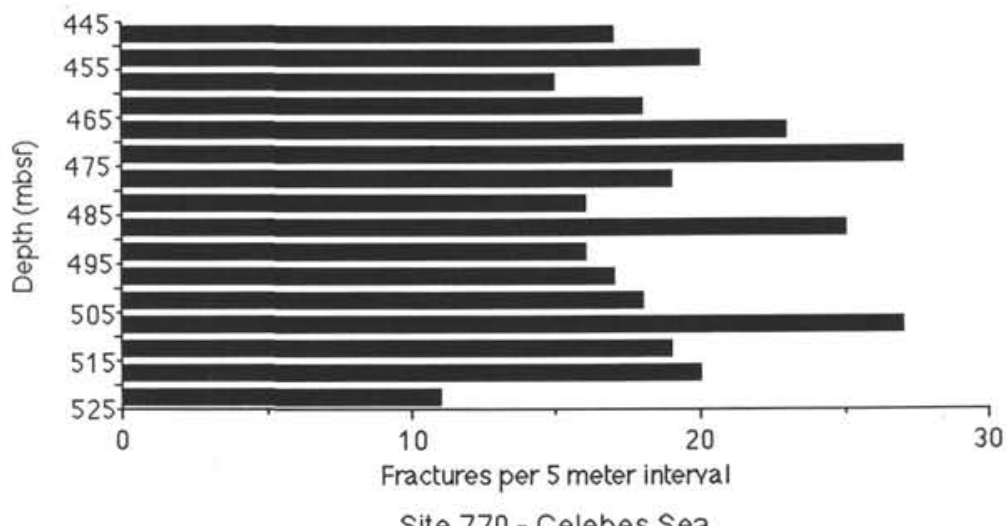

Figure 9. Bar graphs of number of fractures per 5-m section for (A) Site 768 and (B) Site 770 . Frequency pattern may be related to lithologies involved.

Table 1. Sulu Sea (Site 768) and Celebes Sea (Site 770) fracture orientations.

\begin{tabular}{llll}
\hline $\begin{array}{c}\text { Well } \\
\text { Location }\end{array}$ & \multicolumn{1}{c}{ Strike } & Dip & \multicolumn{1}{c}{ Notes } \\
\hline Sulu Sea & $\mathrm{N} 120^{\circ} \mathrm{E}$ & $60^{\circ} \mathrm{SW}$ & main cluster \\
Sulu Sea & $\mathrm{N} 117^{\circ} \mathrm{E}$ & $62^{\circ} \mathrm{NE}$ & secondary cluster \\
Sulu Sea & $\mathrm{N} 64^{\circ} \mathrm{E}$ & $68^{\circ} \mathrm{SE}$ & secondary cluster \\
Sulu Sea & $\mathrm{N} 35^{\circ} \mathrm{E}$ & $64^{\circ} \mathrm{E}$ & secondary cluster \\
Celebes Sea & $\mathrm{N} 119^{\circ} \mathrm{E}$ & $68^{\circ} \mathrm{NE}$ & sills and flows only \\
Celebes Sea & $\mathrm{N} 143^{\circ} \mathrm{E}$ & $70^{\circ} \mathrm{SW}$ & sills and flows only \\
\hline
\end{tabular}

these Sites. Higher bottom hole temperatures will cause higher thermal stresses. However, the actual temperature difference may be lower due to warming of the drilling fluid as it travels through the pipe past warmer rock.

The presence of thermal cracks requires a large ratio of effective horizontal stresses and a strike-slip faulting regime (with normal or reverse components) (Moos and Zoback, 1990). The fracture orientations observed in SItes 768 and 770 appear to represent conjugate shear fractures formed in a normal faulting regime. Therefore, we only calculated the effect of thermal stresses in a normal/strike-slip faulting regime. As shown on Figure 10, these results indicate that thermal fractures may be possible at Site 768, but are not indicated for Site 770 . Using the range of possible $T, E$, $v$, and $\alpha$, reported above, we calculated the range of possible $\sigma \theta$ and $T^{*}$ values at each site. For Site $768,15.9 \mathrm{MPa} \leq \sigma \theta \leq 35.8$ $\mathrm{MPa}$ and $-12.8 \mathrm{MPa} \leq T^{*} \leq 18.1 \mathrm{MPa}$. At Site $770,10.6 \mathrm{MPa}$ $\leq \sigma \theta \leq 23.9 \mathrm{MPa}$ and $1 \mathrm{MPa} \leq T^{*} \leq 23.4 \mathrm{MPa}$. These results indicate that, if $E$ and $\alpha$ are very high and $T$ and + are very low, thermal fracturing is possible at both sites. If the fractures observed in Sites 768 and 770 are of thermal origin, they indicate a maximum horizontal stress azimuth of $\mathrm{N} 130^{\circ} \mathrm{E}$ in the Sulu Sea and N $120^{\circ}$ E in the Celebes Sea.

\section{Alternative Explanations}

The preferred orientations of fractures at these sites may represent a response to the present stress field, either by formation of new fractures or reactivation of older features. The close similarity of the fracture trends in these basins of disparate ages (Silver and Rangin, this volume) leads us to suspect that they are a result of the present stress field. High-angle fractures can form in either conjugate strike-slip or normal faulting environments (Spencer, 1977). A conjugate strike-slip origin for the fractures at Sites 768 and 770 seems less likely because the predicted pattern of conjugate fracture sets were not observed (Figs. 6, 7, 8, and Table 1).

Extensional stress at these sites may be due to flexure of the oceanic crust as it travels through the hinge line of the Negros and Cotabato trenches. Although gravity measurements suggest that Site 770 is located slightly trenchward of 
Site 768 - Sulu Sea

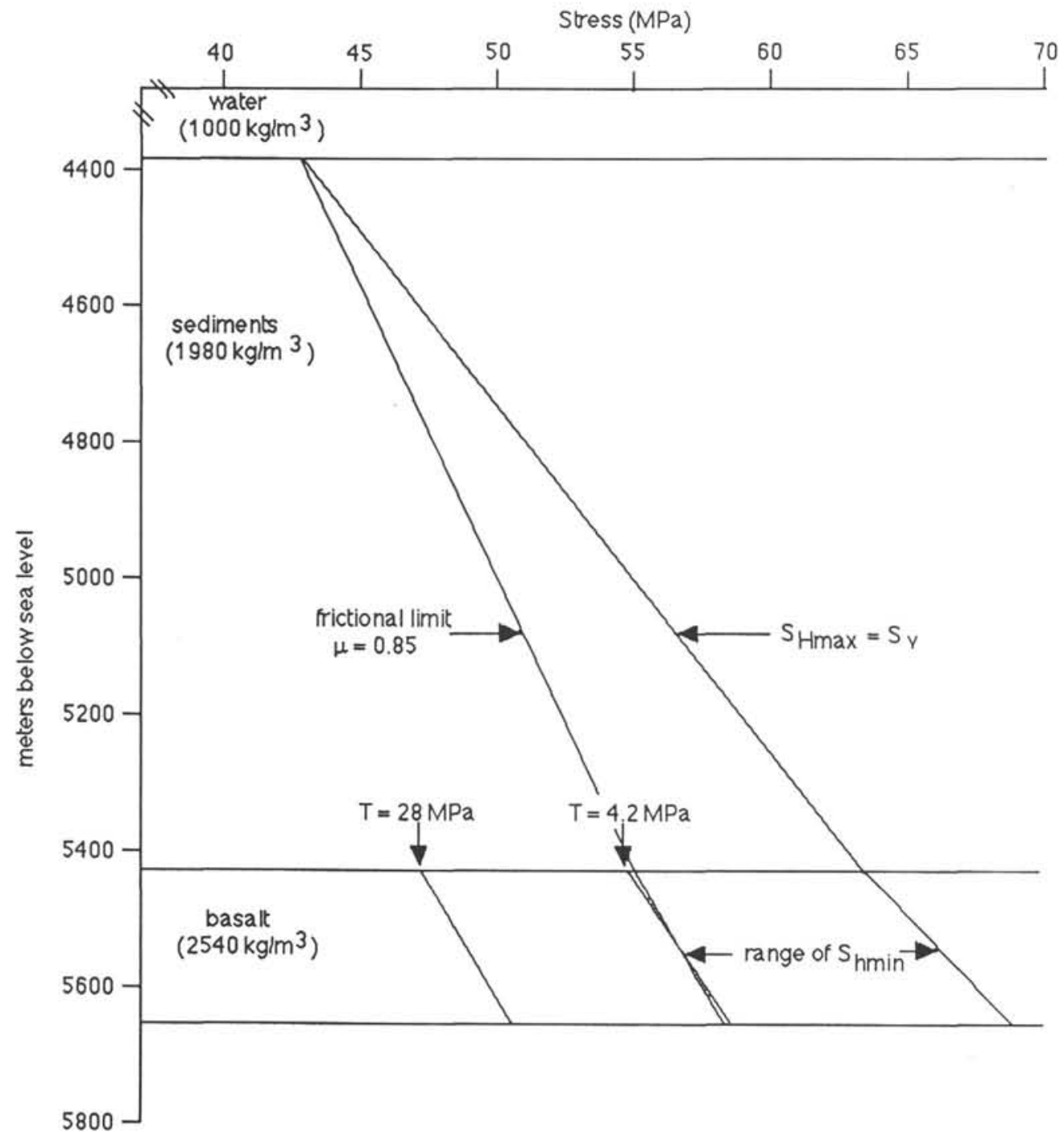

Site 770 - Celebes Sea

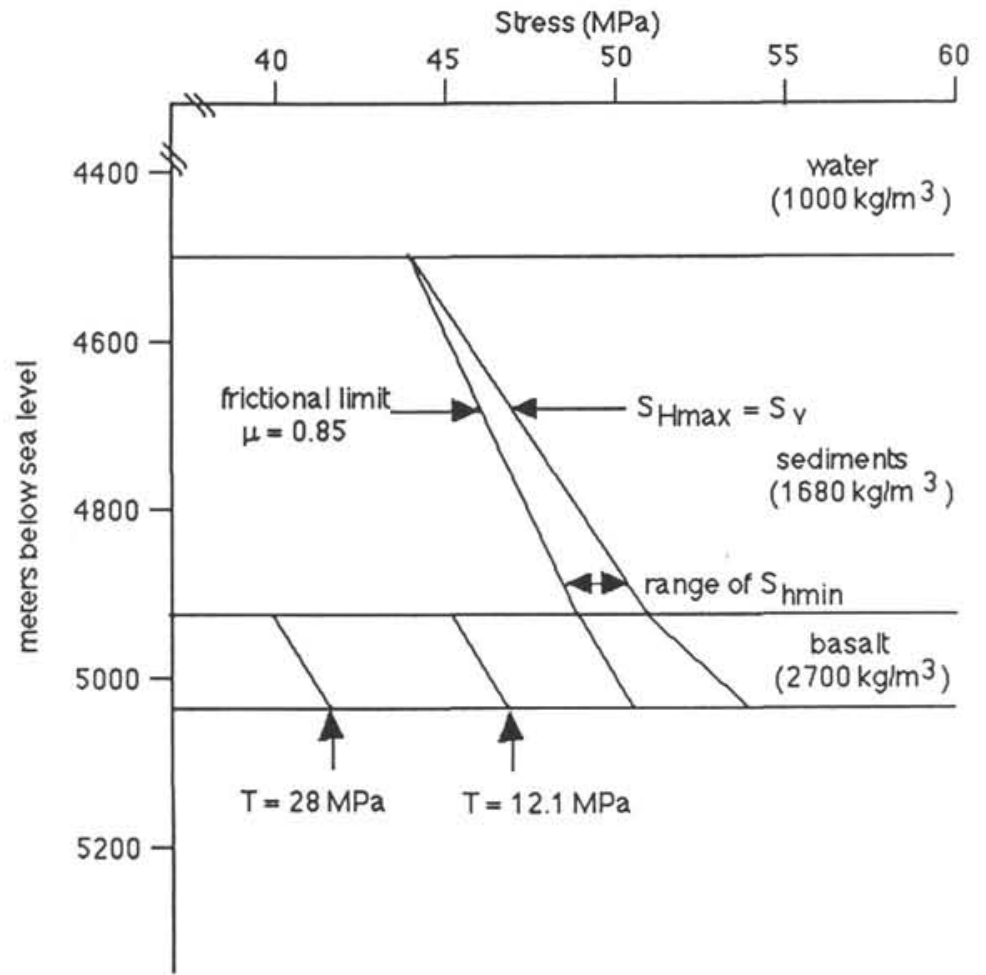

Figure 10. Diagrams of possible stress conditions for normal/strike-slip faulting stress regime for (A) Site 768 and (B) Site 770 . These were calculated using the thicknesses and densities shown on the diagrams. The frictional limit is determined using equation (1) with $\mathrm{S}_{\mathrm{H} \max }=\mathrm{S}_{\mathrm{v}}$. Lines marked $\mathrm{T}=28.5 \mathrm{MPa}$ indicate the values of $\mathrm{S}_{\mathrm{hmin}}$ over which tensile failure would occur if thermal stresses are ignored. Lines marked $\mathrm{T}=4.2 \mathrm{MPa}$ on $(\mathbf{A})$ and $12.1 \mathrm{MPa}$ on $(\mathbf{B})$ indicate values of $\mathrm{S}_{\mathrm{hmin}}$ over which tensile failure will occur due to thermal stresses. See text for details. Note that thermal fracturing may be possible at Site 768 , but requires very low $\mathrm{S}_{\mathrm{hmin}}$. 
the axis of the outer high of the Cotabato Trench, there is no gravitational evidence for a Negros outer trench high near Site 768 (Watts, 1975a). Site 768 is located $110 \mathrm{~km}$ from the axis of the Negros Trench. This distance is compatible with the range of 80 to $150 \mathrm{~km}$ for trench-axis to outer-high-axis distances observed in the northwest Pacific (Watts, 1975a; Watts, 1975b; Watts et al., 1978; Jones et al., 1979), suggesting that Site 768 may be located near or on the outer high of the Negros trench.

Except for areas undergoing regional compression, models of oceanic lithosphere predict extensional stresses of up to 5-10 kbar (5-10 GPa) as a plate enters a trench (Forsyth, 1980). This stress is much greater than that necessary to cause failure in rocks at the depths found at site 768 and 770 (Figs. 4 and 5). The fault patterns of seaward trench slopes consist of normal faults striking parallel or sub-parallel to the trench axis (Jones et al., 1979). The fracture pattern seen at Sites 768 and 770 , i.e., parallel fractures with approximately $60^{\circ}$ dips to the east and west (Figs 6, 7, and 8, and Table 1), suggest that they are conjugate shear fractures formed in a normal faulting stress regime. Also, normal faults with offsets $\leq 30 \mathrm{~cm}$ were found in the core from the tuff section of Site 768 (Rangin, Silver, von Breymann, et al., 1990). These microfaults had high apparent dip, with an average dip of $80^{\circ}$. They were attributed to a normal fault crossing the core between 800 and 900 mbsf.

Descriptions of the basement section of the core noted a more random distribution of $v$-shaped tear fractures and microfaults filled with calcite and hematite. Rangin, Silver, von Breymann, et al. (1990) report that neither the azimuth (relative to split core) or dip of these features had any consistency and suggest that they were probably related to cooling of the basalt and did not reflect regional stresses. No report on the microstructures in the core of Hole $770 \mathrm{C}$ was compiled. As discussed above, a statistically significant portion of the fractures imaged in the BHTV log for both Sites 768 and 770 are high angle and trend $\mathrm{N} 117^{\circ} \mathrm{E}$ to $\mathrm{N} 120^{\circ} \mathrm{E}$. Two possibilities can explain these observations: (1) new fractures formed in response to the present stress field (aided perhaps by thermal stresses in Hole $768 \mathrm{C}$ ) or (2) relict features that have reopened in response to the present stress field.

Most studies of natural fractures (Seeburger and Zoback, 1982; Hickman et al., 1985) show no relationship between natural fracture orientations and regional stress conditions. However, Hickman et al. (1985) report steeply dipping natural fractures that tended to strike sup-parallel to the direction of maximum compressive stress in the lower sedimentary section of the Auburn (NY) well. Fracture orientations in the upper sedimentary and basement sections of this well showed random orientations. The preferred orientation of the fractures in the lower sedimentary section also parallel a late Paleozoic joint set that is normally found only in formations of the upper sedimentary section. These formations are separated from the lower section by a décollement. Although Hickman et al. (1985) could not state with certainty that the preferred fracture orientations they observed were related to the present stress field, it may be that under certain combinations of stress and rock strength such fractures will form.

The clustering of fracture strikes between $120^{\circ} \mathrm{E}$ and $140^{\circ}$ E observed at Sites 768 and 770 suggests that $S_{\text {hmin }}$ trends about $\mathrm{N} 40^{\circ} \mathrm{E}$. This direction is close to the extensional stress direction expected for the Negros and Cotabato trenches near these sites and matches the stress orientations predicted if these are thermal fractures.

We know of no microearthquake studies in the Sulu and Celebes sea basins, and there have not been any normal faulting earthquakes near the drill sites large enough to appear on studies of regional seismicity. Evidence of normal faulting could verify that these fractures are due to present stress conditions if the nodal planes are oriented similar to the fractures.

A third possibility is that the fractures are relict structures formed earlier in the basins' histories. A number of seismic reflection surveys of the Sulu and Celebes basins and a Sea Beam study of the Sulu Sea were completed in preparation for Leg 124. These data imaged several large normal-faulted blocks in the Sulu Sea that trend N $30^{\circ}$ E (Rangin, Silver, von Breymann, et al., 1990). The trend of these faults closely matches one of the less significant preferred fracture orientations observed at Site $768\left(\mathrm{~N} 30^{\circ} \mathrm{E}, 64^{\circ} \mathrm{W}\right)$. Based on the results of Leg 124, these faults are believed to have ceased activity in the Miocene. Site 768 is located $55 \mathrm{~km}$ from the inactive Sulu Trench, which trends N $20^{\circ}$ E. This is subparallel to the same minor preferred orientation as the fault blocks.

In the Celebes Sea, normal faults trending $\mathrm{N} 63^{\circ} \mathrm{E}$ have been mapped using seismic reflection data (Rangin, Silver, von Breymann, et al., 1990). Although the strike of these faults is poorly constrained, it is similar to the trend of magnetic anomalies in this area. We found no preferred fracture orientations that parallel this trend.

No large structures have been mapped that record a stress orientation similar to that predicted by the fractures observed in Sites 768 and 770 except the active trenches. This does not conclusively disprove a relict origin for these fractures, but it does make such an origin unlikely. Further detailed studies of the basement cores from these sites may show if these fractures are relict features. If the high-angle fractures in the core have a random pattern, as described in the study of microstructures at Site 768 (Rangin, Silver, von Breymann et al., 1990), then the preferred orientation of fractures observed in the BHTV data may reflect the current stress. Alternatively, only these fractures may be visible in the BHTV data due to a unique attribute such as a weak infilling material. However, preliminary descriptions of the cores from both sites did not identify any differences in fracture fill (Rangin, Silver, von Breymann, et al., 1990).

We prefer the interpretation that the fractures seen in the BHTV logs record the present stress field, but we cannot rule out other alternatives. We hope that this work will spur further investigations of rock strength for the basement sections of the cores. Additional study of the flexural stresses expected at these sites as well as microearthquake studies could help determine the cause of these fracture patterns.

\section{CONCLUSIONS}

Borehole televiewer logs were collected from 950-1250 mbsf and 809-870 mbsf at Site 768 and from 405-524 mbsf at Site 770. Analysis of these data has shown that no borehole breakouts occur in the logged intervals at these sites. This result is consistent with calculations showing that the allowable tectonic stress field at the deepest logged depth at each site is much lower than that required to cause breakouts (Figs. 4 and 5).

Analysis of the fracture orientations visible in the borehole televiewer logs shows similar preferred fracture trends and dips at both sites. In the Celebes Sea (Site 770), we found a clustering of fracture orientations at $\mathrm{N} 119^{\circ} \mathrm{E}, 68^{\circ} \mathrm{NE}$ and $\mathrm{N}$ $143^{\circ} \mathrm{E}, 70^{\circ} \mathrm{SW}$. This grouping was more pronounced in the sills and flows of the lower basement than in the brecciated pillows above them. In the Sulu Sea (Site 768), our analysis showed a main trend at $\mathrm{N} 120^{\circ} \mathrm{E}, 60^{\circ} \mathrm{SW}$ with smaller groupings at $\mathrm{N} 117^{\circ} \mathrm{E}, 62^{\circ} \mathrm{NE} ; \mathrm{N} 64^{\circ} \mathrm{E}, 68^{\circ} \mathrm{SE}$, and $\mathrm{N} 35^{\circ} \mathrm{E}$, $64^{\circ} \mathrm{E}$. These preferred orientations may represent a response 
to the present stress field either by reactivation of older features or formation of new fractures. The formation of new fractures at Site 768 may have been facilitated by thermal stresses due to cooling of the wellbore by drilling fluids. The fractures could also be relict features from an earlier, shared stress event. If the fractures are due to the present stress field they indicate a minimum horizontal stress direction of $\approx \mathrm{N} 40^{\circ}$ $\mathrm{E}$, suggesting that they might be conjugate shear fractures formed in response to a normal faulting stress regime related to subduction in the Negros and Cotabato trenches. We prefer the interpretation that the fractures record the present stress field, but cannot completely discard other alternatives.

\section{REFERENCES}

Anderson, E. M., 1951. The Dynamics of Faulting and Dike Formation with Applications in Britain (2nd. ed.): Edinburgh (Oliver and Boyd).

Anderson, E. M., and Zoback, M. D., 1982. Permeability, underpressures, and convection in the oceanic crust near the Costa Rica Rift, eastern equatorial Pacific. J. Geophys. Res., 87:2860-2868.

Barton, C. A., 1988. Development of in-situ stress measurement techniques for deep drillholes [Ph.D. dissert.]. Stanford Univ.

Barton, C. A., Tesler, L. G., Zoback, M. D., in press. Interactive image analysis of borehole televiewer data. In Palaz, I., and Sengupta, S. K. (Eds.), Automated Pattern Recognition in Exploration Geophysics: New York (Springer-Verlag).

Barton, C. A., Zoback, M. D., and Burns, K. L., 1988. In-situ stress orientation and magnitude at the Fenton Geothermal site, New Mexico, determined from wellbore breakouts. Geophys. Res. Lett., 15:467-470.

Bauer, S. J., and Handin, J., 1985. Mechanical properties of basalt cores from Deep Sea Drilling Project Hole 504B. In Anderson, R. N., Honnorez, J., Becker, K., et al., Init. Repts. DSDP, 83: Washington (U.S. Govt. Printing Office), 371-378.

Bell, J. S., and Gough, D. I., 1979. Northeast-southwest compressive stress in Alberta: evidence from oil wells. Earth Planet. Sci. Lett., 45:475-482.

Brace, W. F., and Kohlstedt, D. L., 1980. Limits on lithospheric stress imposed by laboratory experiments. J. Geophys. Res., $85: 6248-6252$.

Byerlee, J. D., 1968. Brittle-ductile transition in rocks. J. Geophys. Res., 73:4741-4750.

, 1978. Friction of rocks. Pure Appl. Geophys., 116:615-626.

Carmichael, R. S., 1982. Handbook of Physical Properties of Rocks (Vol. 2): Boca Raton, Fla. (CRC Press).

Clark, S. P., (Ed.), 1966. Handbook of Physical Constants: Mem. Geol. Soc. Am., 97.

Forsyth, D. W., 1980. Comparison of mechanical models of the oceanic lithosphere. J. Geophys. Res., 85:6364-6368.

Georgi, D. T., 1985. Geometrical aspects of borehole televiewer images. Trans. SPWLA Annu. Logging Symp., 26:1-20.

Gradstein, F. M., Ludden, J. N., et al., 1990. Proc. ODP, Init. Repts., 123: College Station, TX (Ocean Drilling Program).

Hickman, S. H., Langseth, M. G., and Svitek, J. F., 1984. In situ permeability and pore-pressure measurements near the Mid-Atlantic Ridge, Deep Sea Drilling Project Hole 395A. In Hyndman, R. D., Salisbury, M. H., et al., Init. Repts. DSDP, 78B: Washington (U.S. Govt. Printing Office), 699-708.

Hubbert, M. K., and Willis, D. G., 1957. Mechanics of hydraulic fracturing. J. Pet. Tech., 9:153-168.

Jaeger, J. S., and Cook, N.G.W., 1979. Fundamentals of Rock Mechanics (3rd ed.): New York (Chapman and Hill).

Jones, G. M., Hilde, T.W.C., Sharman, G. F., and Agnew, D. C., 1979. Fault patterns in outer trench walls and their tectonic significance. In Uyeda, S., Murphys, R. W., and Kobayashi, K. (Eds.), Geodynamics of the Western Pacific: Tokyo (Japan Scientific Societies Press).

Kamb, W. B., 1959. Ice petrofabric observations from Blue Glacier, Washington, in relation to theory and experiment. J. Geophys. Res., 64:1891-1910.
Mastin, Larry, 1988. Effect of borehole deviation on breakout orientations. J. Geophys. Res., 93:9187-9195.

Moos, D. and Morin, R. H., in press. Observations of wellbore failure in the Toa Baja well - implication for the state of stress in the northcoast Tertiary Basin, Puerto Rico. Geophys. Res. Lett.

Moos, D., and Zoback, M. D., 1990. Utilization of observations of well bore failure to constrain the orientation and magnitude of crustal stresses: application to continental, Deep Sea Drilling Project, and Ocean Drilling Program boreholes. J. Geophys. Res., 95:9305-9325.

Morin, R. H., Newmark, R. L., Barton, C. A., and Anderson, R. N., 1990. State of lithospheric stress and borehole stability at Deep Sea Drilling Project site 504B, eastern equatorial Pacific. $J$. Geophys. Res., 95:9293-9303.

Newmark, R. L., Anderson, R. N., Moos, D., and Zoback, M. D., 1985. Sonic and ultrasonic logging of Hole 504B and its implications for the structure, porosity and stress regime of the upper 1 $\mathrm{km}$ of the oceanic crust. In Anderson, R. N., Honnorez, J., et al., Init. Repts. DSDP, 83: Washington (U.S. Govt. Printing Office), 479-510.

Rangin, C., Silver, E. A., von Breymann, M. T., et al., 1990. Proc. ODP, Init. Repts., 124: College Station, TX (Ocean Drilling Program).

Seeburger, D. A., and Zoback, M. D., 1982. The distribution of natural fractures and joints at depth in crystalline rock. J. Geophys. Res., 87:5517-5534.

Shipboard Scientific Party, 1986. Site 597. In Leinen, M., Rea, D. K. et al., Init. Repts. DSDP, 92: Washington (U.S. Govt. Printing Office), 25-96.

Sibson, R. H., 1974. Frictional constraints on thrust, wrench, and normal faults. Nature, 249:542-544.

Spencer, E. W., 1977. Introduction to the Structure of the Earth (2nd ed.): San Francisco (McGraw-Hill).

Stephens, G., and Voight, B., 1982. Hydraulic fracturing theory for conditions of thermal stress. Int. J. Rock Mech. Min. Sci., 19:270-284.

Stock, J. M., Healy, J. H., Hickman, S. H., and Zoback, M. D., 1985. Hydraulic fracturing stress measurements at Yucca Mountain, Nevada, and the relationship to the regional stress field. $J$. Geophys. Res., 90:8691-8706.

Watts, A., 1975a. Gravity field of the northwest Pacific ocean basin and its margin: Philippine sea. Geol. Soc. Am. Map and Chart Ser., MC-12.

1975b. Gravity field of the northwest Pacific ocean basin and margin: Aleutian island arc-trench system. Geol. Soc. Am. Map and Chart Ser., MC-10.

Watts, A. B., Kogan, M. G., and Bodine, J. H., 1978. Gravity field of the northwest Pacific ocean basin and margin: Kuril island arctrench system. Geol. Soc. Am. Map and Chart Ser., MC-27.

Zemaneck, J., Glenn, E. E., Norton, L. J., and Caldwell, R. J., 1970. Formation evaluation by inspection with the borehole televiewer. Geophysics, 35:254-269.

Zoback, M. D., Moos, D., Mastin, L., and Anderson, R. N., 1985. Wellbore breakouts and in situ stress. J. Geophys. Res, 90:55235530.

Zoback, M. L., and Zoback, M. D., 1980. State of stress in the conterminous United States. J. Geophys. Res., 85:6113-6156.

Zoback, M. L., Zoback, M. D., Adams, J., Assumpêöo, M., Bell, S., Bergman, E. A., Blümling, P., Brereton, N. R., Denham, D., Ding, J., Fuchs, K., Gay, N., Gregersen, S., Gupta, H. K., Givishiani, A., Jacob, K., Klein, R., Knoll, P., Magee, M., Mercier, J. L., Müller, B. C., Paquin, C., Rajendran, J., Stephensson, O., Suarez, G., Suter, M., Udas, A., Xu, Z. H., and Zhizhin, M., 1989. Global patterns of intraplate stress: a status report on the world stress map project of the International Lithosphere Program. Nature, 241:291-298.

Date of initial receipt: 10 July 1990

Date of acceptance: 13 December 1990

Ms 124B-176 